\title{
Analysis of common and rare VPS13C variants in late-onset Parkinson disease
}

Uladzislau Rudakou, BSc, Jennifer A. Ruskey, MSc, Lynne Krohn, MSc, Sandra B. Laurent, BSc, Dan Spiegelman, MSc, Lior Greenbaum, MD, PhD, Gilad Yahalom, MD, Alex Desautels, MD, PhD, Jacques Y. Montplaisir, MD, PhD, Stanley Fahn, MD, Cheryl H. Waters, MD, Oren Levy, MD, PhD, Caitlin M. Kehoe, MA, Sushma Narayan, MS, Yves Dauvilliers, MD, PhD, Nicolas Dupré, MD, FRCP, Sharon Hassin-Baer, MD, Roy N. Alcalay, MD, MS, Guy A. Rouleau, MD, PhD, FRCPC, FRSC, Edward A. Fon, MD, FRCPC, and Ziv Gan-Or, MD, PhD

Neurol Genet 2020;6:e385. doi:10.1212/NXG.0000000000000385

\section{Abstract}

\section{Objective}

We aimed to study the role of coding VPS13C variants in a large cohort of patients with lateonset Parkinson disease (PD) (LOPD).

\section{Methods}

VPS13C and its untranslated regions were sequenced using targeted next-generation sequencing in 1,567 patients with PD and 1,667 controls from 3 cohorts. Association tests of rare potential homozygous and compound heterozygous variants and burden tests for rare heterozygous variants were performed. Common variants were analyzed using logistic regression adjusted for age and sex in each of the cohorts, followed by a meta-analysis.

\section{Results}

No biallelic carriers of rare VPS13C variants were found among patients, and 2 carriers of compound heterozygous variants were found in 2 controls. There was no statistically significant burden of rare (minor allele frequency $[\mathrm{MAF}]<1 \%$ ) or very rare $(\mathrm{MAF}<0.1 \%)$ coding VPS13C variants in PD. A VPS13C haplotype including the p.R153H-p.I398I-p.I1132V-p.Q2376Q variants was nominally associated with a reduced risk for PD (meta-analysis of the tagging SNP p.I1132V [odds ratio $=0.48,95 \%$ confidence interval $=0.28-0.82, p=0.0052]$ ). This haplotype was not in linkage disequilibrium with the known genome-wide association study top hit.

\section{Conclusions}

Our results do not support a role for rare heterozygous or biallelic VPS13C variants in LOPD. Additional genetic replication and functional studies are needed to examine the role of the haplotype identified here associated with reduced risk for PD.

\author{
Correspondence \\ Dr. Gan-Or \\ ziv.gan-or@mcgill.ca
}




\section{Glossary}

$\mathbf{A J}=$ Ashkenazi Jewish $\mathbf{A N O V A}=$ analysis of variance $\mathbf{C A D D}=$ Combined Annotation Dependent Depletion $\mathbf{C I}=$ confidence interval; EOPD = early onset Parkinson disease; GATK = Genome Analysis Toolkit; GnomAD = Genome Aggregation Database; GQ = quality score; GWAS = genome-wide association study; $\mathbf{L D}=$ linkage disequilibrium; $\mathbf{L O P D}=$ late onset Parkinson disease; $\mathbf{M A F}=$ minor allele frequency; $\mathbf{M I P}=$ molecular inversion probe; $\mathbf{O R}=$ odds ratio; $\mathbf{P D}=$ Parkinson disease; QC = quality control.

The VPS13C gene is located within a risk locus for Parkinson disease (PD), reported in large genome-wide association studies (GWASs) of European population. ${ }^{1,2}$ The single nucleotide polymorphism (SNP) reported in the GWAS (rs2414739, chr15.hg19:g.61994134G>A) was also studied in several Asian populations and in Iranians, with conflicting results, ${ }^{3-7}$ possibly because of ethnicity-related differences.

Subsequently, homozygous and compound heterozygous VPS13C mutations were identified as a rare cause of early onset PD (EOPD) characterized by rapid progression and early cognitive dysfunction. It was demonstrated that VPS13C is partially localized at the mitochondrial membrane, and its silencing led to mitochondrial dysfunction and increased PINK1/Parkin-dependent mitophagy. ${ }^{8} \mathrm{~A}$ follow-up study in 80 patients with EOPD identified an additional patient with compound heterozygous mutations with similar clinical features to the previously reported patients. ${ }^{9}$ In another recent study, a homozygous deletion in VPS13C was reported to be the probable cause of early onset parkinsonism in 1 patient. ${ }^{10}$ Thus far, full sequencing studies of VPS13C have not been reported in late-onset PD (LOPD).

To further study the potential role of VPS13C variants in PD, we sequenced its coding and regulatory regions using targeted next-generation sequencing in 3 cohorts of PD (predominantly LOPD) and in controls. We examined the association of common, rare, and biallelic VPS13C variants on the risk for PD. We further tested whether any coding variant or variants in the untranslated regions of VPS13C are in linkage disequilibrium (LD) with the top VPS13C-associated GWAS hit to determine if any of these variants can explain the GWAS association of this locus.

\section{Methods}

\section{Study population}

Three cohorts, with a total of 1,567 unrelated patients with PD and 1,667 controls, were included in this study, detailed in table 1. The first cohort was composed of French and French Canadian participants recruited in Quebec (Canada) and in France. This cohort was previously genotyped using the GWAS OmniExpress array, the ethnicity was confirmed using principal component analysis, and the samples that were of different ethnicities were not included in this study. The second cohort was recruited in New York-Columbia
University and was previously described. ${ }^{11}$ Most participants from New York are of European descent and 38\% are Ashkenazi Jewish (AJ), $40 \%$ of patients with PD, and $35 \%$ of controls. This difference was not statistically significant, yet we adjusted for ethnicity when analyzing this cohort to avoid effects of ethnicity on the results. The third cohort was recruited in Israel (Sheba Medical Center), and all participants included in this study from the Israeli cohort are of full AJ origin (all 4 grandparents are full AJ). All patients were consecutively recruited through the clinics, and they represent the typical LOPD patient population with age at onset (AAO) of about 60 (table 1), as opposed to the studies published so far on VPS13C in EOPD. As detailed below, because of the differences in age and sex (table 1), statistical analysis was adjusted and included age and sex as covariates. To account for different ethnicities in the New York cohort, an ethnicity covariate was also introduced in this cohort (GWAS data were not available for this cohort; therefore, the reported ethnicity was used and not principal components). All 3 cohorts were sequenced in the same laboratory (McGill University), following the same protocol. All patients with PD were diagnosed by movement disorder specialists according to the UK Brain Bank criteria, ${ }^{12}$ without excluding patients with family history of $\mathrm{PD}$, because it is now known that there are familial cases of PD, so patients who reported family history of PD were included. However, it is important to emphasize that in the current study, only unrelated patients were included and there were no multiple cases from the same family.

\section{Standard protocol approvals, registrations, and patient consents}

The institutional review board (McGill University Health Center Research Ethics Board-MUHC REB) approved the study protocols (reference number IRB00010120). Informed consent was obtained from all individual participants before entering the study.

\section{DNA extraction and VPS13C sequencing}

DNA was extracted using a standard salting out protocol. The coding sequence and regulatory regions of VPS13C were targeted using molecular inversion probes (MIPs), which were designed as previously described. ${ }^{13}$ MIPs were selected based on their predicted coverage, quality, and overlap. All MIPs used to sequence VPS13C in the present study are included in table e-1, links.lww.com/NXG/A205. Targeted DNA capture and amplification was performed as previously described, ${ }^{14}$ and the full protocol is available on request. The 
Table 1 Study population details

\begin{tabular}{|c|c|c|c|c|c|c|c|c|c|c|}
\hline \multirow{2}{*}{\multicolumn{2}{|c|}{ Sequenced }} & \multirow[b]{3}{*}{ Cohort } & \multirow[b]{3}{*}{$\begin{array}{l}\text { Min Depth of } \\
\text { Coverage }\end{array}$} & \multicolumn{6}{|c|}{ Analyzed } & \multirow[b]{3}{*}{$\begin{array}{l}\text { Genotyping } \\
\text { call rate \% }\end{array}$} \\
\hline & & & & \multicolumn{3}{|c|}{ Cases } & \multicolumn{3}{|c|}{ Controls } & \\
\hline $\begin{array}{l}\mathrm{N} \\
\text { (cases) }\end{array}$ & $\begin{array}{l}\mathrm{N} \\
\text { (controls) }\end{array}$ & & & $\mathbf{N}$ & $\begin{array}{l}\text { Mean age } \\
\text { (SD) y }\end{array}$ & $\begin{array}{l}\% \\
\text { Male }\end{array}$ & $\mathbf{N}$ & $\begin{array}{l}\text { Mean Age } \\
\text { (SD) y }\end{array}$ & $\begin{array}{l}\% \\
\text { Male }\end{array}$ & \\
\hline 543 & 866 & $\begin{array}{l}\text { French/French } \\
\text { Canadian }\end{array}$ & $\begin{array}{l}15 x \\
50 x\end{array}$ & $\begin{array}{l}534 \\
498\end{array}$ & $\begin{array}{l}59.7(11.4) \\
59.8(11.2)\end{array}$ & $\begin{array}{l}63.7 \\
63.5\end{array}$ & $\begin{array}{l}858 \\
785\end{array}$ & $\begin{array}{l}42.0(13.6) \\
42.3(13.5)\end{array}$ & $\begin{array}{l}51.6 \\
52.0\end{array}$ & $\begin{array}{l}99.6 \\
99.2\end{array}$ \\
\hline 533 & 270 & New York & $\begin{array}{l}15 x \\
50 x\end{array}$ & $\begin{array}{l}520 \\
502\end{array}$ & $\begin{array}{l}59.3(11.8) \\
59.3(11.8)\end{array}$ & $\begin{array}{l}64.0 \\
64.1\end{array}$ & $\begin{array}{l}262 \\
245\end{array}$ & $\begin{array}{l}65.0(9.8) \\
65.4(9.6)\end{array}$ & $\begin{array}{l}34.0 \\
32.7\end{array}$ & $\begin{array}{l}99.9 \\
99.5\end{array}$ \\
\hline 491 & 531 & Israel & $\begin{array}{l}15 x \\
50 x\end{array}$ & $\begin{array}{l}482 \\
478\end{array}$ & $\begin{array}{l}60.6(11.7) \\
60.7(11.7)\end{array}$ & $\begin{array}{l}61.8 \\
61.7\end{array}$ & $\begin{array}{l}488 \\
487\end{array}$ & $\begin{array}{l}33.9(7.2) \\
33.9(7.2)\end{array}$ & $\begin{array}{l}57.8 \\
57.7\end{array}$ & $\begin{array}{l}99.3 \\
99.3\end{array}$ \\
\hline
\end{tabular}

library was sequenced using an Illumina HiSeq 2,500 platform at the McGill University and Genome Quebec Innovation Centre. Reads were mapped to the human reference genome (hg19) with Burrows-Wheeler Aligner. ${ }^{15}$ Genome Analysis Toolkit (v3.8) was used for postalignment quality control (QC) and variant calling, ${ }^{16}$ and annotation variation was used for annotation. ${ }^{17}$ Data on the frequency of each VPS13C variant were extracted from the public database Genome Aggregation Database (GnomAD).$^{18}$ Validation of the tagging variant p.I1132V was performed using Sanger sequencing, with the following primers: forward 5'-CCGGGAAGGTAATGACAAAA-3' and reverse 5'-CCCCTGATTGAAAAGTCACA-3'.

\section{Quality control}

During QC filtration using PLINK software v1.9, ${ }^{19}$ SNPs with genotyping rate lower than $90 \%$ were excluded. Genotyping rate cut-off for individuals was $90 \%$, and individuals with a lower genotyping rate were excluded. SNPs that deviated from Hardy-Weinberg equilibrium set at $p=0.001$ threshold were filtered out. Threshold for missingness difference between cases and controls was set at $p=0.05$ and the filtration script adjusted it with Bonferroni correction. After these QC steps, cohort composition was as described in table 1 . To be included in the analysis, minimum quality score (GQ) was set to 30. Rare variants (minor allele frequency $[\mathrm{MAF}]<0.01$ or 0.001 ) had to have a minimal coverage of $>50 \times$ to be included, and common variants had to have a minimal coverage of $>15 \mathrm{x}$ to be included in the analysis.

\section{Statistical analysis}

The association between common VPS13C variants and PD was examined by using logistic regression models using PLINK v1.9, with the status (patient or control) as a dependent variable, age and sex as covariates in all cohorts, and $\mathrm{AJ}$ ancestry as an additional covariate in the New York cohort. To analyze rare variants $(\mathrm{MAF}<0.01)$ and very rare variants $(\mathrm{MAF}<0.001)$, an optimized sequence kernel association test (SKAT-O, R package) was performed. ${ }^{20}$ In addition, we examined the burden of predicted pathogenic variants using SKAT-O with Combined Annotation Dependent Depletion (CADD) score of $\geq 12.37$ representing the top $2 \%$ of potentially deleterious variants. The effects of SNP genotypes on the AAO was tested using analysis of variance (ANOVA; in R software). Metaanalysis of common variants in the 3 cohorts was performed using metafor package in $\mathrm{R}$ software. ${ }^{21} \mathrm{LD}$ in our data were examined by PLINK v1.9 and LD between discovered SNPs and the GWAS top hit rs2414739 was tested using LDlink application, selecting all non-Finish Europeans. ${ }^{22}$

\section{Data availability}

Anonymized data are available on request by any qualified investigator.

\section{Results}

\section{Rare VPS13C variants and homozygous or compound heterozygous VPS13C variants are not associated with LOPD}

The average coverage of VPS13C with the MIPs was $94 \%$ of nucleotides covered at $>10 \times$ and $90 \%$ covered at $>50 \times$. This coverage, while not ideal, is better than the whole exome sequencing coverage reported in the original study on VPS13C in PD and better than the whole exome and whole genome sequencing coverage of this specific gene in Gno$\mathrm{mAD}$ (gnomad.broadinstitute.org/). There were no differences in coverage between the cohorts and between patients and controls. A total of 60 rare variants that are nonsynonymous, stop variants, or potentially affect a splicing site were identified in the 3 cohorts and are detailed in table e-2, links.lww.com/NXG/A206.

To examine whether rare homozygous or compound heterozygous VPS13C variants may cause LOPD, and because patients with VPS13C biallelic mutations are very rare, we included only rare variants with allele frequency $<0.001$ in this analysis. Only 2 carriers of 2 heterozygous variants were identified, and both were controls (table e-3, links.lww.com/ NXG/A207), suggesting that biallelic mutations are not common in LOPD. Of note, we did not examine whether these 2 variants were on the same allele or different allele (compound heterozygous) because they were found only in controls, which 
suggests that rare biallelic variants are not involved in LOPD in our cohorts.

To further study a potential role for rare (allele frequency $<0.01$ ) or very rare (allele frequency $<0.001$ ) VPS13C nonsynonymous or splice variants in LOPD, a SKAT-O was performed on the variants detailed in table e-2, links.lww. com/NXG/A206. In the French and French Canadian cohort, $33(6.6 \%)$ patients with PD carried a rare variant compared with $49(6.2 \%)$ in controls. In the NY cohort, 43 patients with PD (8.6\%) carried a rare variant compared with $29(11.8 \%)$ in controls. In the Israeli cohort, 57 (11.9\%) patients with PD carried a rare variant compared with 59 (12. $1 \%)$ among controls. There was no association between rare variants (French/French Canadian cohort $p=0.44$, New York cohort $p=0.34$, and Israel cohort $p=0.91$ ) or very rare variants (French/French Canadian cohort $p=0.17$, New York cohort $p=0.85$, and Israel cohort $p=0.89$ ) and PD. We further examined whether rare variants that are predicted to be deleterious based on CADD score $\geq 12.37$ are enriched in $\mathrm{PD}$ (the variants included in this analysis are detailed in table e-4, links.lww.com/NXG/A208), and no association was found (French/French Canadian cohort $p=0.58$, New York cohort $p=0.39$, and Israel cohort $p=0.40$ ).

\section{A VPS13C haplotype including the p.R153H- p.I398I-p.I1132V-p.Q2376Q coding variants is nominally associated with reduced risk for PD}

We have identified 14 common coding variants in our cohort of French and French Canadians and 13 such variants in each of the NY and Israeli cohorts. More details on the number of carriers and frequencies can be found in table e-5, links.lww. $\mathrm{com} / \mathrm{NXG} / \mathrm{A} 209$. To test whether common coding variants in VPS13C are associated with LOPD, logistic regression models adjusted for age and sex were performed and additional adjustment for ethnicity was included in the New York cohort (see methods). A nominal association was observed in 4 variants (p.R153H [rs12595158, chr15.hg19:g.62316035C >T], p.I398I [rs9635356, chr15.hg19:g.62299603T>G], p.I1132V [rs3784635, chr15.hg19: g.62254989T>C], and p.Q2376Q [rs17238189, chr15.hg19: g.62212781T $>$ C]) with reduced risk for PD in the New York cohort (table 2). These remained nominally significant with and without including adjustment for ethnicity, suggesting that ethnicity has no role in this

Table 2 Four variants forming the protective haplotype found in VPS13C and the results of the logistic regression in 3 cohorts

\begin{tabular}{|c|c|c|c|c|c|c|c|c|c|c|}
\hline Variant & rs number & $\begin{array}{l}\text { nt- } \\
\text { substitution }\end{array}$ & Cohort & $\begin{array}{l}\mathrm{N} \\
\text { (cases) }\end{array}$ & $\begin{array}{l}\mathrm{N} \\
\text { (controls) }\end{array}$ & $\begin{array}{l}\text { Affected } \\
\text { MAF }\end{array}$ & $\begin{array}{l}\text { Unaffected } \\
\text { MAF }\end{array}$ & $\begin{array}{l}\text { GnomAD } \\
\text { MAF }^{\mathrm{a}}\end{array}$ & OR $(95 \% \mathrm{Cl})$ & $\begin{array}{l}p \\
\text { Value }\end{array}$ \\
\hline \multirow[t]{3}{*}{ p.R153H } & rs12595158 & c.G458A & $\mathrm{F} / \mathrm{FC}$ & 15 & 27 & 0.0143 & 0.0157 & 0.0734 & $\begin{array}{l}0.56 \\
(0.26-1.20)\end{array}$ & 0.1358 \\
\hline & & & NY & 14 & 16 & 0.0135 & 0.0324 & & $\begin{array}{l}0.38 \\
(0.17-0.84)\end{array}$ & 0.0172 \\
\hline & & & Israel & 16 & 22 & 0.0166 & 0.0225 & 0.0236 & $\begin{array}{l}0.70 \\
(0.19-2.6)\end{array}$ & 0.5940 \\
\hline \multirow[t]{3}{*}{ p.1398I } & rs9635356 & c.A1194C & F/FC & 15 & 28 & 0.0143 & 0.0163 & 0.0737 & $\begin{array}{l}0.56 \\
(0.26-1.20)\end{array}$ & 0.1330 \\
\hline & & & NY & 16 & 16 & 0.0154 & 0.0324 & & $\begin{array}{l}0.42 \\
(0.20-0.91)\end{array}$ & 0.0274 \\
\hline & & & Israel & 15 & 19 & 0.0156 & 0.0195 & 0.0214 & $\begin{array}{l}0.75 \\
(0.19-2.89)\end{array}$ & 0.6752 \\
\hline \multirow[t]{3}{*}{ p.I1132V } & rs3784635 & c.A3394G & $\mathrm{F} / \mathrm{FC}$ & 15 & 26 & 0.0143 & 0.0152 & 0.0726 & $\begin{array}{l}0.69 \\
(0.32-1.48)\end{array}$ & 0.3404 \\
\hline & & & NY & 11 & 18 & 0.0106 & 0.0363 & & $\begin{array}{l}0.28 \\
(0.12-0.64)\end{array}$ & 0.0025 \\
\hline & & & Israel & 14 & 19 & 0.0145 & 0.0195 & 0.0233 & $\begin{array}{l}0.65 \\
(0.16-2.65)\end{array}$ & 0.5444 \\
\hline \multirow[t]{3}{*}{ p.Q2376Q } & rs17238189 & c.A7128G & $\mathrm{F} / \mathrm{FC}$ & 10 & 24 & 0.0095 & 0.0140 & 0.0698 & $\begin{array}{l}0.51 \\
(0.21-1.23)\end{array}$ & 0.1344 \\
\hline & & & NY & 16 & 17 & 0.0154 & 0.0344 & & $\begin{array}{l}0.42 \\
(0.20-0.90)\end{array}$ & 0.0245 \\
\hline & & & Israel & 16 & 20 & 0.0166 & 0.0215 & 0.0212 & $\begin{array}{l}0.47 \\
(0.07-3.10)\end{array}$ & 0.4350 \\
\hline
\end{tabular}

Abbreviations: $\mathrm{Cl}=$ confidence interval; F/FC = French/French Canadian; GnomAD = genome aggregation database; MAF = minor allele frequency; nt = nucleotide; $O R=$ odds ratio.

a GnomAD_ASJ frequencies were used for the Israeli cohort; all samples are Ashkenazi Jewish. 
association and only one of them, p. I1132V (odds ratio 0.28 , $95 \%$ confidence interval $0.12-0.64, p=0.0025)$, remained statistically significant after correction for multiple comparisons. In the 2 other cohorts, these variants showed the same directionality as in the New York cohort but did not reach statistical significance (table 2). These 4 variants, p.R153H, p.I398I, p.I1132V, and p.Q2376Q are in strong or even complete LD (table e-6, links.lww.com/NXG/A210). The most significant tagging SNP of this haplotype, p. I1132V, was validated using Sanger sequencing in all 3 cohorts. Metaanalysis of all the common coding variants showed an association of these 4 linked SNPs with reduced risk for PD (figure), with similar directionality across all cohorts. To examine whether this haplotype may affect AAO of PD, ANOVA with the status of the $\mathrm{p}$. I1132V variant was performed. This variant was not associated with AAO in all 3 cohorts (French/French Canadian cohort $p=0.65$, New York cohort $p=0.34$, and Israel cohort $p=0.99$ ).

None of these variants were in LD with the known GWAS top hit, rs2414739, and therefore, these associations do not explain the GWAS hit in the VPS13C locus. Of all the other common coding variants, only one variant, p.E2008D (rs78071599, chr15.hg19: g.62223303C >G), was in some LD with the GWAS top hit $\left(D^{\prime}=0.808, r^{2}=0.006\right.$, table e-7, links. lww.com/NXG/A211), but this variant was not associated with LOPD, and therefore, it also cannot explain the GWAS hit in our populations. Of interest, an intronic variant, rs78530361 (chr15.hg19: g.62214265C>T), was in LD with the top GWAS SNP $\left(D^{\prime}=1, r^{2}=0.003\right)$. Of note, $r^{2}$ is low since this intronic SNP has a much lower allele frequency than the top GWAS hit, but every time the rs78530361 SNP is found, it is on an allele which harbors the top GWAS hit rs2414739. However, in our cohorts, this variant was not associated with PD $(p=0.66)$, likely because of its very low $\mathrm{r}^{2}$ with the GWAS hit.

\section{Discussion}

Our study, which included full sequencing of VPS13C in 3 cohorts, identified 60 rare VPS13C variants (MAF <0.01) that are nonsynonymous or affect splicing and 18 common variants (MAF >0.01) in coding regions of the gene and splice sites. Our results suggest that rare homozygous and compound heterozygous variants are rare in LOPD and probably have importance mainly in EOPD, as previously described. We have identified a potentially protective haplotype, which includes 4 variants, 2 of which are substitutions of amino acids, p.R153H and p.I1132V. The association was mainly driven by the NY cohort, but the 2 other cohorts demonstrated similar directionality of effect and effect size and also contributed to the association. It is unlikely that differences in ethnicity in the NY cohort drove the association because

Figure Forest plots-meta-analyses of 4 VPS13C coding variants associated with reduced risk for PD

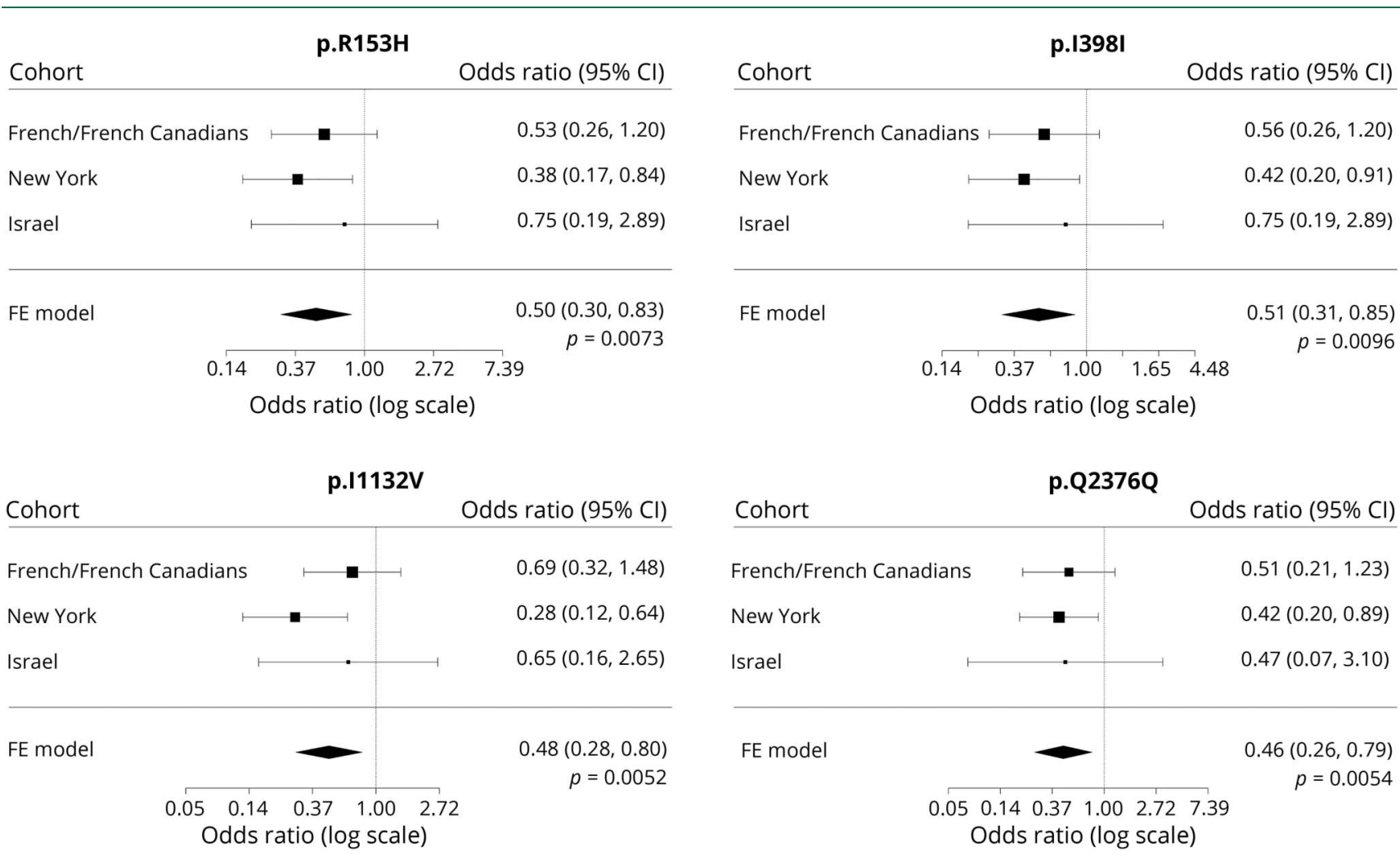

The forest plots depict the effects of the 4 VPS13C coding variants that create the haplotype associated with reduced PD risk in the 3 cohorts studied and their meta-analyzed effect on risk for PD. The results in the random effect model are nearly identical. $\mathrm{Cl}=$ confidence interval; $\mathrm{FE}=$ fixed effect; $\mathrm{PD}=\mathrm{Parkinson}$ disease. 
analysis was with adjustment for ethnicity and analysis without adjustment yielded nearly identical results, ruling out the effect of ethnicity. The other 2 cohorts were of homogeneous ethnicities; therefore, in these cohorts too, ethnicity could not have affected the results. Of interest, this haplotype is not in LD with the top GWAS SNP, rs2414739, suggesting that this may be a secondary association in the VPS13C locus, which was not identified in the previous studies. However, this should be considered as preliminary results and needs to be examined in additional cohorts to conclude whether this haplotype is indeed associated with reduced risk for PD. Because the disease-causing mutations reported in VPS13C are loss-of-function mutations, a protective effect could occur, for example, because of the gain of function or overexpression. In GTEx (gtexportal.org/home/), these variants were not associated with increased expression or affect splicing. The 2 nonsynonymous variants of this haplotype, p.R153H and $\mathrm{p}$. I1132V, have high CADD scores (22.8 and 13.7, respectively), suggesting that they may affect the protein structure or function. Whether there is such effect and whether it is associated with gain-of-function mutation will need to be examined in follow-up studies. Furthermore, the full sequencing analysis did not identify any coding variant that is in LD, with the original GWAS hit that can explain the GWAS association in this locus. This may suggest that the variant that has the main effect on the risk for $\mathrm{PD}$ in the VPS13C is outside of the coding and untranslated regions of the gene, likely being a regulatory element.

Previous studies on the top GWAS hit in the VPS13C locus demonstrated conflicting results. Although significant associations of the top GWAS hit in this locus (rs2414739) with PD were found in Iranian $^{5}$ and East Asian ${ }^{3}$ populations, negative results were reported in Taiwanese ${ }^{4}$ and Han Chinese $^{6,7}$ populations. Therefore, it is possible that the association of VPS13C with PD is population dependent. Of note, the association in the current study was mainly driven by populations enriched in Ashkenazi Jews, whereas in the French/French Canadian cohort, the differences between patients and controls were much smaller and not statistically significant (table 2). This may suggest that this haplotype association is population specific, and additional studies in different populations are required to answer this question.

In our 3 cohorts, we did not find any very rare homozygous variants with MAF $<0.001$ and found only 2 carriers of 2 heterozygous variants, both of which were controls (table e-3, links.lww.com/NXG/A207). We were unable to determine if the variants were in cis or trans, but because no carriers of 2 variants were found among patients, it is clear that VPS13C biallelic mutations do not contribute to PD in our cohorts. Previously reported cases of PD in carriers of compound heterozygous or homozygous mutations, all shared a specific clinical presentation of PD: early onset, rapid progression, and early cognitive dysfunction. ${ }^{8,9}$ In 1 study, the patient's AAO was 39 and disease progression was moderately severe with psychiatric symptoms and impaired cognition. ${ }^{9}$ In another study, the 3 patients showed severe phenotypes: AAO of 25, 33 , and 46 years, severe and early cognitive dysfunction, and became bedridden at 31,43 , and 58 years, respectively. Considering the young age of one of the compound heterozygous VPS13C variant carriers in our cohort (30 years), it is still possible although unlikely that this individual will develop $\mathrm{PD}$ in the future. The negative results of the SKAT-O analyses demonstrate that rare heterozygous variants in VPS13C do not have an important role in PD in our cohorts.

Our study has several limitations. The differences between patients with PD and controls in sex and mainly age are significant in some of our cohorts. To address this limitation, we included age and sex as covariates in the regression models. Therefore, if the association of the protective haplotype was related to age and not to disease status, we would likely not observe an association in the adjusted model. Furthermore, the association with the haplotype had the same directionality and similar effect size in the NY cohort in which the controls were older (and the association was statistically significant), and in the other 2 cohorts, where the controls were younger, likely ruling out the effect of age. There was no significant difference in the percentage of Ashkenazi Jews between patients and controls in the New York cohort, yet we still performed the regression model with and without ethnicity as a covariate, and in both analyses, the results remained significant. Nevertheless, the fact that our populations are enriched with relatively homogeneous populations such as Ashkenazi Jews and French Canadians requires additional studies in other populations. Another potential limitation is that we could not analyze the effect of CNVs in VPS13C with our data. Loss of function and exonic deletions/duplications are rare in gnom $A D$, found in only 3 individuals at a heterozygous state, and therefore not likely to have a major contribution in PD. However, future studies to examine the potential role of VPS13C in PD are required. Furthermore, because no functional experiments were performed in the current study, the potential effects of variants that we report here should be examined in additional studies.

In conclusion, our results suggest that VPS13C variants have a limited role in late-onset PD. The potentially PD protective haplotype located within VPS13C, which requires additional replications, may suggest that VPS13C could be a future target for PD therapeutic development. If naturally occurring genetic variants may reduce PD risk, it is conceivable that drugs that can mimic their effects could be developed. Additional genetic and functional studies will be required to determine if VPS13C may be a viable target for PD drug development.

\section{Acknowledgment}

The authors thank the patients and control subjects for their participation in this study. This work was financially supported by the Michael J. Fox Foundation, the Canadian Consortium on Neurodegeneration in Aging (CCNA), and the Canadian Glycomics Network (GlycoNet). This research was also undertaken in part to funding from the Canada First 
Research Excellence Fund (CFREF) awarded to McGill University for the Healthy Brains for Healthy Lives (HBHL) program. The Columbia University cohort is supported by the Parkinson's Foundation, the National Institutes of Health [K02NS080915 and UL1 TR000040], and the Brookdale Foundation. GAR holds a Canada Research Chair in Genetics of the Nervous System and the Wilder Penfield Chair in Neurosciences. EAF is supported by a foundation grant from the Canadian Institutes of Health Research (FDN grant 154301). ZGO is supported by the Fonds de recherche du Québec - Santé (FRQS) Chercheurs-boursiers award and by the Young Investigator Award by Parkinson Canada. The access to part of the participants for this research has been made possible thanks to the Quebec Parkinson's Network (rpq-qpn.ca/en/). The authors thank Armaghan Alam, Daniel Rochefort, Helene Catoire, Clotilde Degroot, and Vessela Zaharieva for their assistance.

\section{Study funding}

This work was financially supported by the Michael J. Fox Foundation, the Canadian Consortium on Neurodegeneration in Aging (CCNA), and the Canadian Glycomics Network (GlycoNet). This research was also undertaken in part to funding from the Canada First Research Excellence Fund (CFREF), awarded to McGill University for the Healthy Brains for Healthy Lives (HBHL) program. The Columbia University cohort is supported by the Parkinson's Foundation, the NIH [K02NS080915 and UL1 TR000040], and the Brookdale Foundation.

\section{Disclosure}

Disclosures available: Neurology.org/NG.

\section{Publication history}

Received by Neurology: Genetics July 20, 2019. Accepted in final form October 23, 2019.

Appendix Authors

\begin{tabular}{|c|c|c|c|}
\hline Name & Location & Role & Contribution \\
\hline $\begin{array}{l}\text { Uladzislau } \\
\text { Rudakou, } \\
\text { BSc }\end{array}$ & $\begin{array}{l}\text { McGill University, } \\
\text { Montreal, QC, } \\
\text { Canada }\end{array}$ & Author & $\begin{array}{l}\text { Analyzed and } \\
\text { interpreted the data; } \\
\text { performed validations; } \\
\text { drafted the manuscript } \\
\text { for intellectual content }\end{array}$ \\
\hline $\begin{array}{l}\text { Jennifer A. } \\
\text { Ruskey, MSc }\end{array}$ & $\begin{array}{l}\text { McGill University, } \\
\text { Montreal, QC, } \\
\text { Canada }\end{array}$ & Author & $\begin{array}{l}\text { Major role in the } \\
\text { acquisition of data; } \\
\text { revised the manuscript } \\
\text { for intellectual content }\end{array}$ \\
\hline $\begin{array}{l}\text { Lynne } \\
\text { Krohn, MSc }\end{array}$ & $\begin{array}{l}\text { McGill University, } \\
\text { Montreal, QC, } \\
\text { Canada }\end{array}$ & Author & $\begin{array}{l}\text { Interpreted the data; } \\
\text { revised the manuscript } \\
\text { for intellectual content }\end{array}$ \\
\hline $\begin{array}{l}\text { Sandra B. } \\
\text { Laurent, BSc }\end{array}$ & $\begin{array}{l}\text { McGill University, } \\
\text { Montreal, QC, } \\
\text { Canada }\end{array}$ & Author & $\begin{array}{l}\text { Major role in the } \\
\text { acquisition of data; } \\
\text { Interpreted the data; } \\
\text { revised the manuscript } \\
\text { for intellectual content }\end{array}$ \\
\hline
\end{tabular}

Appendix (continued)

\begin{tabular}{|c|c|c|c|}
\hline Name & Location & Role & Contribution \\
\hline $\begin{array}{l}\text { Dan } \\
\text { Spiegelman, } \\
\text { MSc }\end{array}$ & $\begin{array}{l}\text { McGill University, } \\
\text { Montreal, QC, } \\
\text { Canada }\end{array}$ & Author & $\begin{array}{l}\text { Major role in the } \\
\text { acquisition of data; } \\
\text { revised the manuscript } \\
\text { for intellectual content }\end{array}$ \\
\hline $\begin{array}{l}\text { Lior } \\
\text { Greenbaum, } \\
\text { MD, PhD }\end{array}$ & $\begin{array}{l}\text { Sheba Medical } \\
\text { Center, Tel } \\
\text { Hashomer, Ramat } \\
\text { Gan, Israel }\end{array}$ & Author & $\begin{array}{l}\text { Major role in the } \\
\text { acquisition of data; } \\
\text { revised the manuscript } \\
\text { for intellectual content }\end{array}$ \\
\hline $\begin{array}{l}\text { Gilad } \\
\text { Yahalom, } \\
\text { MD }\end{array}$ & $\begin{array}{l}\text { Sheba Medical } \\
\text { Center, Tel } \\
\text { Hashomer, Ramat } \\
\text { Gan, Israel }\end{array}$ & Author & $\begin{array}{l}\text { Major role in the } \\
\text { acquisition of data; } \\
\text { revised the manuscript } \\
\text { for intellectual content }\end{array}$ \\
\hline $\begin{array}{l}\text { Alex } \\
\text { Desautels, } \\
\text { MD, PhD }\end{array}$ & $\begin{array}{l}\text { Université de } \\
\text { Montréal, } \\
\text { Montreal, QC, } \\
\text { Canada }\end{array}$ & Author & $\begin{array}{l}\text { Major role in the } \\
\text { acquisition of data; } \\
\text { revised the manuscript } \\
\text { for intellectual content }\end{array}$ \\
\hline $\begin{array}{l}\text { Jacques Y. } \\
\text { Montplaisir, } \\
\text { MD, PhD }\end{array}$ & $\begin{array}{l}\text { Université de } \\
\text { Montréal, } \\
\text { Montreal, QC, } \\
\text { Canada }\end{array}$ & Author & $\begin{array}{l}\text { Major role in the } \\
\text { acquisition of data; } \\
\text { revised the manuscript } \\
\text { for intellectual content }\end{array}$ \\
\hline $\begin{array}{l}\text { Stanley } \\
\text { Fahn, MD }\end{array}$ & $\begin{array}{l}\text { Columbia } \\
\text { University, New } \\
\text { York, NY, USA }\end{array}$ & Author & $\begin{array}{l}\text { Major role in the } \\
\text { acquisition of data; } \\
\text { revised the manuscript } \\
\text { for intellectual content }\end{array}$ \\
\hline $\begin{array}{l}\text { Cheryl H. } \\
\text { Waters, MD }\end{array}$ & $\begin{array}{l}\text { Columbia } \\
\text { University, New } \\
\text { York, NY, USA }\end{array}$ & Author & $\begin{array}{l}\text { Major role in the } \\
\text { acquisition of data; } \\
\text { revised the manuscript } \\
\text { for intellectual content }\end{array}$ \\
\hline $\begin{array}{l}\text { Oren Levy, } \\
\text { MD, PhD }\end{array}$ & $\begin{array}{l}\text { Columbia } \\
\text { University, New } \\
\text { York, NY, USA }\end{array}$ & Author & $\begin{array}{l}\text { Major role in the } \\
\text { acquisition of data; } \\
\text { revised the manuscript } \\
\text { for intellectual content }\end{array}$ \\
\hline $\begin{array}{l}\text { Caitlin M. } \\
\text { Kehoe, MA }\end{array}$ & $\begin{array}{l}\text { Columbia } \\
\text { University, New } \\
\text { York, NY, USA }\end{array}$ & Author & $\begin{array}{l}\text { Major role in the } \\
\text { acquisition of data; } \\
\text { revised the manuscript } \\
\text { for intellectual content }\end{array}$ \\
\hline $\begin{array}{l}\text { Sushma } \\
\text { Narayan, MS }\end{array}$ & $\begin{array}{l}\text { Columbia } \\
\text { University, New } \\
\text { York, NY, USA }\end{array}$ & Author & $\begin{array}{l}\text { Major role in the } \\
\text { acquisition of data; } \\
\text { revised the manuscript } \\
\text { for intellectual content }\end{array}$ \\
\hline $\begin{array}{l}\text { Yves } \\
\text { Dauvilliers, } \\
\text { MD, PhD }\end{array}$ & $\begin{array}{l}\text { University of } \\
\text { Montpellier, } \\
\text { Montpellier, } \\
\text { France }\end{array}$ & Author & $\begin{array}{l}\text { Major role in the } \\
\text { acquisition of data; } \\
\text { revised the manuscript } \\
\text { for intellectual content }\end{array}$ \\
\hline $\begin{array}{l}\text { Nicolas } \\
\text { Dupré, MD, } \\
\text { FRCP }\end{array}$ & $\begin{array}{l}\text { Université Laval, } \\
\text { Québec City, QC, } \\
\text { Canada }\end{array}$ & Author & $\begin{array}{l}\text { Major role in the } \\
\text { acquisition of data; } \\
\text { revised the manuscript } \\
\text { for intellectual content }\end{array}$ \\
\hline $\begin{array}{l}\text { Sharon } \\
\text { Hassin-Baer, } \\
\text { MD }\end{array}$ & $\begin{array}{l}\text { Sheba Medical } \\
\text { Center, Tel } \\
\text { Hashomer, Ramat } \\
\text { Gan, Israel }\end{array}$ & Author & $\begin{array}{l}\text { Major role in the } \\
\text { acquisition of data; } \\
\text { revised the manuscript } \\
\text { for intellectual content }\end{array}$ \\
\hline $\begin{array}{l}\text { Roy N. } \\
\text { Alcalay, MD, } \\
\text { MS }\end{array}$ & $\begin{array}{l}\text { Columbia } \\
\text { University, New } \\
\text { York, NY, USA }\end{array}$ & Author & $\begin{array}{l}\text { Major role in the } \\
\text { acquisition of data; } \\
\text { revised the manuscript } \\
\text { for intellectual content }\end{array}$ \\
\hline $\begin{array}{l}\text { Guy A. } \\
\text { Rouleau, } \\
\text { MD, PhD, } \\
\text { FRCPC, FRSC }\end{array}$ & $\begin{array}{l}\text { McGill University, } \\
\text { Montreal, QC, } \\
\text { Canada }\end{array}$ & Author & $\begin{array}{l}\text { Major role in the } \\
\text { acquisition of data; } \\
\text { revised the manuscript } \\
\text { for intellectual content }\end{array}$ \\
\hline
\end{tabular}

Continued 
Appendix (continued)

\begin{tabular}{|c|c|c|c|}
\hline Name & Location & Role & Contribution \\
\hline $\begin{array}{l}\text { Edward A. } \\
\text { Fon, MD }\end{array}$ & $\begin{array}{l}\text { McGill University, } \\
\text { Montreal, QC, } \\
\text { Canada }\end{array}$ & Author & $\begin{array}{l}\text { Major role in the } \\
\text { acquisition of data; } \\
\text { revised the manuscript } \\
\text { for intellectual content }\end{array}$ \\
\hline $\begin{array}{l}\text { Ziv Gan-Or, } \\
\text { MD, PhD }\end{array}$ & $\begin{array}{l}\text { McGill University, } \\
\text { Montreal, QC, } \\
\text { Canada }\end{array}$ & Author & $\begin{array}{l}\text { Designed and } \\
\text { conceptualized study; } \\
\text { major role in the } \\
\text { acquisition of data; } \\
\text { assisted with } \\
\text { interpretation of the } \\
\text { data revised the } \\
\text { manuscript for } \\
\text { intellectual content; led } \\
\text { and coordinated } \\
\text { communication among } \\
\text { sites. }\end{array}$ \\
\hline
\end{tabular}

\section{References}

1. Nalls MA, Pankratz N, Lill CM, et al. Large-scale meta-analysis of genome-wide association data identifies six new risk loci for Parkinson's disease. Nat Genet 2014;46: 989-993.

2. Chang D, Nalls MA, Hallgrímsdóttir IB, et al. A meta-analysis of genome-wide association studies identifies 17 new Parkinson's disease risk loci. Nat Genet 2017;49: 1511-1516.

3. Zou M, Li R, Wang JY, et al. Association analyses of variants of SIPA1L2, MIR4697, GCH1, VPS13C, and DDRGK1 with Parkinson's disease in East Asians. Neurobiol Aging 2018;68:159.e7-159.e14.

4. Chen CM, Chen YC, Chiang MC, et al. Association of GCH1 and MIR4697, but not SIPA1L2 and VPS13C polymorphisms, with Parkinson's disease in Taiwan. Neurobiol Aging 2016;39:221-225.

5. Safaralizadeh T, Jamshidi J, Esmaili Shandiz E, et al. SIPA1L2, MIR4697, GCH1 and VPS13C loci and risk of Parkinson's diseases in Iranian population: a case-control study. J Neurol Sci 2016;369:1-4.
6. Wang L, Cheng L, Li NN, Yu WJ, Sun XY, Peng R. Association of four new candidate genetic variants with Parkinson's disease in a Han Chinese population. Am J Med Genet B Neuropsychiatr Genet 2016;171B:342-347.

7. Yang X, Zheng J, An R, et al. Polymorphism in MIR4697 but not VPS13C, GCH1, or SIPA1L2 is associated with risk of Parkinson's disease in a Han Chinese population. Neurosci Lett 2017;650:8-11.

8. Lesage S, Drouet V, Majounie E, et al. Loss of VPS13C function in autosomalrecessive parkinsonism causes mitochondrial dysfunction and increases PINK1/ parkin-dependent mitophagy. Am J Hum Genet 2016;98:500-513.

9. Schormair B, Kemlink D, Mollenhauer B, et al. Diagnostic exome sequencing in earlyonset Parkinson's disease confirms VPS13C as a rare cause of autosomal-recessive Parkinson's disease. Clin Genet 2018;93:603-612.

10. Darvish H, Bravo P, Tafakhori A, et al. Identification of a large homozygous VPS13C deletion in a patient with early-onset Parkinsonism. Mov Disord 2018;33:1968-1970.

11. Alcalay RN, Levy OA, Wolf $\mathrm{P}$, et al. SCARB2 variants and glucocerebrosidase activity in Parkinson's disease. NPJ Parkinsons Dis Epub 2016 Mar 10.

12. Hughes AJ, Daniel SE, Kilford L, Lees AJ. Accuracy of clinical diagnosis of idiopathic Parkinson's disease: a clinico-pathological study of 100 cases. J Neurol Neurosurg Psychiatry 1992;55:181-184.

13. O'Roak BJ, Vives L, Fu W, et al. Multiplex targeted sequencing identifies recurrently mutated genes in autism spectrum disorders. Science 2012;338:1619-1622.

14. Ross JP, Dupre N, Dauvilliers Y, et al. Analysis of DNAJC13 mutations in French-Canadian/ French cohort of Parkinson's disease. Neurobiol Aging 2016;45:212 e213-212 e217.

15. Li H, Durbin R. Fast and accurate short read alignment with Burrows-Wheeler transform. Bioinformatics 2009;25:1754-1760.

16. McKenna A, Hanna M, Banks E, et al. The Genome Analysis Toolkit: a MapReduce framework for analyzing next-generation DNA sequencing data. Genome Res 2010, 20:1297-1303.

17. Wang $\mathrm{K}, \mathrm{Li}$ M, Hakonarson $\mathrm{H}$. ANNOVAR: functional annotation of genetic variants from high-throughput sequencing data. Nucleic Acids Res 2010;38:e164.

18. Lek M, Karczewski KJ, Minikel EV, et al. Analysis of protein-coding genetic variation in 60,706 humans. Nature 2016;536:285-291.

19. Purcell S, Neale B, Todd-Brown K, et al. PLINK: a tool set for whole-genome association and population-based linkage analyses. Am J Hum Genet 2007;81:559-575.

20. Lee S, Emond MJ, Bamshad MJ, et al. Optimal unified approach for rare-variant association testing with application to small-sample case-control whole-exome sequencing studies. Am J Hum Genet 2012;91:224-237.

21. Viechtbauer W. Conducting meta-analyses in R with the metafor package. J Stat Softw 2010;36.

22. Machiela MJ, Chanock SJ. LDlink: a web-based application for exploring populationspecific haplotype structure and linking correlated alleles of possible functional variants. Bioinformatics 2015;31:3555-3557. 


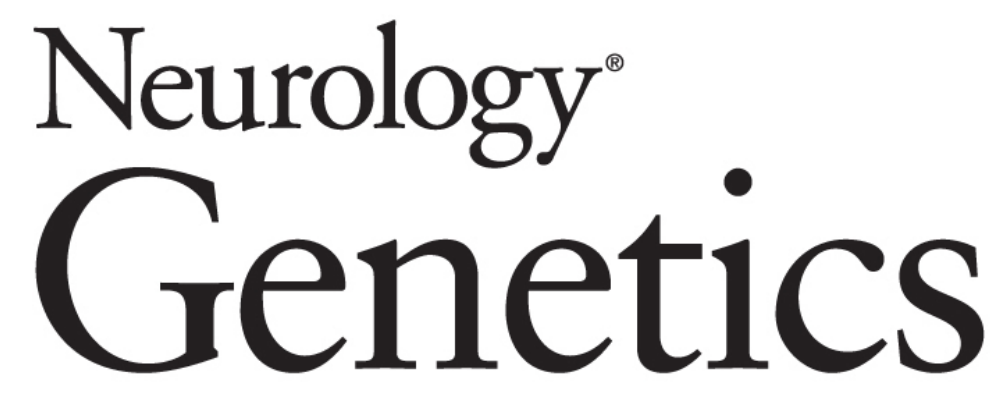

\section{Analysis of common and rare VPS13C variants in late-onset Parkinson disease Uladzislau Rudakou, Jennifer A. Ruskey, Lynne Krohn, et al. \\ Neurol Genet 2020;6; \\ DOI 10.1212/NXG.0000000000000385}

This information is current as of January 9,2020

\section{Updated Information \& Services}

References

Citations

Subspecialty Collections

Permissions \& Licensing

Reprints including high resolution figures, can be found at: http://ng.neurology.org/content/6/1/385.full.html

This article cites 20 articles, 3 of which you can access for free at: http://ng.neurology.org/content/6/1/385.full.html\#\#ref-list-1

This article has been cited by 8 HighWire-hosted articles: http://ng.neurology.org/content/6/1/385.full.html\#\#otherarticles

This article, along with others on similar topics, appears in the following collection(s):

Association studies in genetics

http://ng.neurology.org//cgi/collection/association_studies_in_genetics Case control studies

http://ng.neurology.org//cgi/collection/case_control_studies

Parkinson's disease/Parkinsonism

http://ng.neurology.org//cgi/collection/parkinsons_disease_parkinsonis $\mathrm{m}$

Information about reproducing this article in parts (figures,tables) or in its entirety can be found online at:

http://ng.neurology.org/misc/about.xhtml\#permissions

Information about ordering reprints can be found online: http://ng.neurology.org/misc/addir.xhtml\#reprintsus

Neurol Genet is an official journal of the American Academy of Neurology. Published since April 2015, it is an open-access, online-only, continuous publication journal. Copyright Copyright $\odot 2020$ The Author(s). Published by Wolters Kluwer Health, Inc. on behalf of the American Academy of Neurology.. All rights reserved. Online ISSN: 2376-7839.

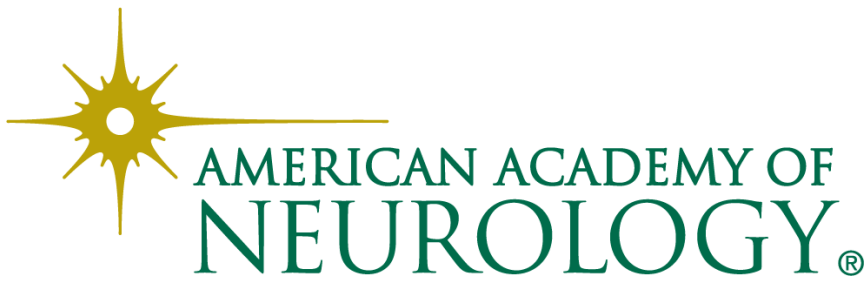

